\title{
Effects of Substitution Barley By 10\%, 30\% of Sprouted Barley on Rumen Characters, Digestibility and Feed Efficiency in Diet of Awassi Male Lambs
}

\author{
M.J.AL-Saadi ${ }^{1}$, Ibrahim A. H. Al-Zubiadi ${ }^{2}$ \\ Researcher, Department of Hygiene, College of Veterinary Medicine- University of Baghdad. Baghdad-Iraq \\ Assistant Professor, Zoonotic Disease Unit, College of Veterinary Medicine- University of Baghdad. Baghdad-Iraq
}

\begin{abstract}
Current study is aims to cultivate and produce of sprouted barley under local conditions and evaluate the effect this products on some characters of rumen, and Efficiency of feed and Digestibility in Awassi male lambs, in the completely block, 18 lambs, and by the weight randomly divided into three group 6 lambs to each $, 10 \%, 30 \%$,sprouted barley supplementation and either control (grain barley ) respectively were fed for 120 days, total diet calculated on dry matter basis, seeds were growing in hydroponic system using perforated trays carried on chamber in 7days of growth period, the rumen characters trail reveled that there is significantly $(<0.05)$ higher values in treated groups in activity of microflora, amount of volatile fatty acids compared to control group while, there is reduction in $\mathrm{pH}$ value of treated group in comparative to control group, digestibility trail determined significantly $(<0.05)$ higher values in treated groups in conversion ratio in all nutrient content of sprouted barley except in crud fiber digestibility, in nutrients conversion performance of barley grain to sprouted barley the study revealed significantly $(<0.05)$ higher value in most parameter except in true protein and an increasing in fresh sprouts weight, about 4.22 times per $\mathrm{kg}$ of grain, but, dry matter obtained was less than the initial origin grain ,furthermore the dry matter losses in fresh sprouted barley but there was significantly increasing in crud protein as a dry basis in compared to grain ,it can be concluded that substitution of barley grain particularly by $30 \%$ sprouted barley as a total dry matter in lambs diet gives good improvements in some rumen characters as well as in most nutrient digestibility and feeding efficiency therefore we recommended to substitute barley by sprouted barley in more higher percentage mixed with concentrate diet of ruminants.
\end{abstract}

Keywords: sprouted barley, supplementation

\section{Introduction}

Sprouted barley is a new methods of forage grains production without soil, which having high germination rate and grown for a short period. The idea of this new germination method is to take a maximum with uniform growth of plants and controlling the amount of water, ATLAS Global (1) .Germination and sprouting activates enzymes change the starch, protein, and lipids of the grain into simpler forms Tudor. et. al., (2). This method may be especially important in the regions where forage production is limited; ATLAS Global (1).Fresh sprouted barley produced is of such high quality that it is suitable even for all livestock, World wild (3). The digestion of cellulose contained is most other high DM feeds is a accomplished, not by the secretions from the glands of animals, but by bacteria that inhabit the elementary canal and breaks down the complex carbohydrates into readily assailable products, Steven (4). Crude protein is maintained at $16 \%$ to $17 \%$. A vitro digestibility of over than $85 \%$ was observed, ATLAS Global (1). The passage of the ingested material to be delayed optimum conditions of temperature, moisture and acidity for the action of the bacteria to accomplish the digestive process. because of its palatability and digestibility coupled with high crude protein (amino acids) accelerate the digestive process of the other less digestive feeds and reduces the stress factor on the animal, Steven (4). The production fresh green feed can be important element of overall ration, which has been proven to improve livestock health, reduce heat stress and increase birth rates, World wild (3). few research has been conducted to determine the feeding value of hydroponically sprouted grains,
Thomas.(5), Peer, ea.al.,(6),but because the price of animal feed has increased globally, alternative feeds with competitive prices must be developed however ,The system produces feed by organic growth and it is taken very little space as compared to traditional methods of agriculture. To this end, the objective of this study was to investigate the effect of including $10 \%$ and $30 \%$ levels of whole fresh sprouting barley calculated as dry weight in the concentrate diets of Awassi lambs on rumen physiology and feeding efficiency.

\section{Materials and Methods}

\subsection{The Experimental Design}

The study was conducted for 120 days period,at Animal Farm subsequent to College of Veterinary Medicine / Baghdad University, Eighteen Awassi male lambs purchased from local trusted farms with average body weight of $19.25 \pm 0.25 \mathrm{~kg}$ and four month ages at the start of the experiments. Experimental Lambs treated with anti ecto and endo parasites and vaccinated against enterotoxaemia, they were weighed and ranked according to live weight. Then herd was split into 3 groups based upon their weight at the start of the trial 6 Lambs in each after two weeks of adaptation period. All groups were daily feed with $2 \%$ of body weight of concentrate diet, the control Group were daily fed only $2 \%$ concentrate diet, the second , third groups of lambs were fed with same amount of concentrate diet include $10 \%$ and $30 \%$ of fresh sprouting barely respectively, all groups supplied with water and mineral blocks ad lipt 


\section{International Journal of Science and Research (IJSR) \\ ISSN (Online): 2319-7064 \\ Index Copernicus Value (2013): 6.14 | Impact Factor (2015): 6.391}

.The amount of feed offered to the lambs and the remaining were weighed and recorded daily

Table 1: The formulation of experimental dietary concentrate composition (\%)

\begin{tabular}{|c|c|c|c|}
\hline \multirow{2}{*}{ Ingredients \% } & \multicolumn{3}{|c|}{ Treatment } \\
\cline { 2 - 4 } & $0 \%$ control & $10 \%$ & $30 \%$ \\
\hline Barley grain & 40 & 30 & 10 \\
\hline Fresh sprouting barely & 0 & 10 & 30 \\
\hline Wheat bran & 38 & 38 & 38 \\
\hline Yellow corn & 20 & 20 & 20 \\
\hline Mineral \&vitamin & 2 & 2 & 2 \\
\hline Total & 100 & 100 & 100 \\
\hline
\end{tabular}

* Each kg of vitamin and mineral mixture contained $0.30 \mathrm{~g}$ CoSO4, 20.1 g CuSO4, 10 g FeSO4, 50 g ZnO2, 40.2 g MnSO4, 0.75 g KI, 878 g NaCl, 500,000 IU vitamin A, 500,000 IU vitamin D and 10,000 IU vitamin E, according to AOAC. 1995 (7).

\section{Fresh sprouted barley daily feed intake for each lambs calculation ,: \\ body weight $(\mathrm{kg}) \times 2 \%=(\mathrm{N}) \mathrm{kg}$ concentrate diet daily feed intake 100 \\ $(\mathrm{N}) \times 10 \%$ or $30 \%=(\mathrm{kg})$ of dry weight of sprouted barely 100}

\subsection{Sprouts barley production}

Hydroponic cultivation and chemical analyses of sprouted grain used according to (6).The forages production plan was conducted using one of hydroponic steel chamber, with dimensions of 2.0 m length X 2.0 m height X 1.0 m width designed to carrying 21 steel perforated trays, with capacity seven growth stages by rely of seven days, trays were used to germinate barley seeds with dimensions of $100 \mathrm{~cm}$ length $\mathrm{X} 40 \mathrm{~cm}$ width and $5 \mathrm{~cm}$ height to each equipped with manual sprayer irrigation water and electric air ventilation, the condition inside the Rome chamber was controlled to get a range of temperature $18-20 \mathrm{c}$ and relative humidity about $72 \%$ by air circulating. Fluorescent lighting with watertight appliance were provide on the wall in the vertical position to growing leaves in when supply about 1000 microwatt/ cm3 during 9-12 hours of daily light. Barley seeds(Hordeum vulgare L) were got from a local supplier, which were Cleaned, washed and soaked by tap water ,putting in container for $24 \mathrm{~h}$, then spread on the trays With $1.1 \mathrm{~kg}$ and $2 \mathrm{~cm}$ thickness, for each and stayed, for 7 days. At end of this period the grass of barley seedling growth reaches about of $16-18 \mathrm{~cm}$ in height t. It has carpet like appearance with dark green color and thick roots. Three trays were planted and three green grass carpets were removed every day, though, it required seventh days for each one cycle of seeds germination have to acquire continues daily harvesting of green forages, removal carpets exposed to air ventilation for 24 hours in order to more drying, then weighing and shredded by hands to small pieces, before calculated and mixing with concentrate diets.

\section{Chemical Analysis}

Weekly samples of green forage, diets collected and kept frozen until chemical analysis for crude protein, crude fiber, crude fat, nitrogen free extract AOAC.1995 (7) (Table 2).
The feed and the remaining were sampled daily and composted until the end of the collection period. Which were grounded through a $1 \mathrm{~mm}$-screen hammer mill and analyzed for $\mathrm{DM}$ (at $70^{\circ} \mathrm{C}$ ) and nutrients composition according to AOAC. 1999 (8) The samples were dried in electric oven at $100^{\circ} \mathrm{C}$ until constant weight, Daily fecal were collected at 7:30 a.m., weighed and dried at $60^{\circ} \mathrm{C}$ Yuangklang et. al., (9). The remaining fecal was composted and stored at $4^{\circ} \mathrm{C}$ for further test AOAC. 1999 (8)

\section{Digestibility Trial}

Digestibility Trial were conducted to determine the digestibility coefficients of the diets, animals groups were housed in metabolic cages throughout the entire experiment, The concentrate ingredients were prepared and combined weekly, while the roughage and concentrate were mixed manually every day and fed as total mixed ration (TMR), feed and water were offered twice a day at 9:00 a.m. and 15.00 p.m. The amount of feed offered and the remaining were weighed and recorded daily, Dry matter intake, and feed conversion ratio were calculated by weekly.

\section{Rumen fluid samples}

$10 \mathrm{ml}$ Rumen fluid samples from each animals were collected before the morning feeding by stomach tube at last four weeks of the experiment to estimate the volatile fatty acids levels ,pH , and. the activity of the rumen microflora .AL-Ani (10), Joshi,et. al .,(11), M.J.AL-SAADI .et. al.,(12)

\section{Statistical Analysis}

Duncan's tests were conducted to compare the means of each treatment, and the data were analyzed by using the statistical analysis (SPSS, version 19) Snedecor et .al.,(.(13)

\section{Results and Discussion}

\subsection{Feed Conversion Performance}

Table (2) shown that there were significantly $(<0.05)$ higher values in most nutrient conversion ratio of barley grain to sprouts for most feeds components including fresh weight, dry matter weight ,organic matter ,crud protein ,ether extract, NDF, ADF, NFC, WSC except true protein which were recorded a non significant value.

Table 1: Feeding conversion performance of barley grain to sprouted barley .

\begin{tabular}{|c|c|c|c|c|}
\hline Item & $\begin{array}{c}\text { Barley } a \\
\text { grain }(\mathrm{g})\end{array}$ & $\begin{array}{c}\text { Greed } b \\
\text { fodder (g) }\end{array}$ & CRc & Significance \\
\hline Fresh weight & 1000.00 & 4220.20 & $\mathbf{4 . 2 2}$ & $*$ \\
\hline DM weight & 903.70 & 815.07 & $\mathbf{0 . 9 0}$ & $*$ \\
\hline Organic matter ns & 887.69 & 806.40 & $\mathbf{0 . 9 0}$ & $*$ \\
\hline Crude protein & 95.8 & 130.66 & $\mathbf{1 . 3 6}$ & $*$ \\
\hline True protein & 64.98 & 65.22 & $\mathbf{1 . 0 5}$ & Ns \\
\hline Ether extract & 13.21 & 26.32 & $\mathbf{1 . 9 9}$ & $*$ \\
\hline Neutral detergent fiber & 213.15 & 274.36 & $\mathbf{1 . 2 8}$ & $*$ \\
\hline Acid detergent fiber & 85.55 & 133.40 & $\mathbf{1 . 5 5}$ & $*$ \\
\hline Non fiber carbohydrate & 512.96 & 437.90 & $\mathbf{0 . 8 5}$ & $*$ \\
\hline $\begin{array}{c}\text { Water soluble } \\
\text { carbohydrate }\end{array}$ & 38.49 & 68.33 & $\mathbf{1 . 7 7}$ & $*$ \\
\hline
\end{tabular}




\section{International Journal of Science and Research (IJSR) ISSN (Online): 2319-7064 \\ Index Copernicus Value (2013): 6.14 | Impact Factor (2015): 6.391}

*: statistically significant $(\mathrm{P}<0.05)$. ns: statistically not significant $(\mathrm{P}>0.05)$. $a$ The conversion ratio (CR) for each nutrient calculated as below:

Nutrients contents in green fodder obtained per kg of barley grain $\mathrm{CR}=$

Nutrients contents per kg of barley

The Fresh weight of sprouted barley recorded a significantly $(<0.05)$ higher values than origin grain, from one kilogram of grain yielded more than four times weight of sprouts after seven days of implantation ,this increasing mainly due to amount of water uptake via seeds germination ,such result is declare in experiment that confirmed, the production conversion ratio, based on the amount of fresh fodder produced per weight unit of the seed grain, ranged approximately 4 to 8 times Peer.et.al., (6). Sneath.et.al., (14) explained in study that soaking barley grain pre-steeping of seeds and prior to germination, enables the seeds to imbibe water and swell, which later allows for the splitting of the seeds coat as well as the part of endosperm to absorb water minerals by the roots which would gradually increase the final weight. however, conversion ratio of fresh weight of sprouts could be affected by several factors such as type of grain, variety, management factors, irrigation, temperature, humidity, lights, density of barley seeds on each tray and the number of growing days Trubey et.al., (20).Dry matter including Organic Matter of origin grain significantly $(<0.05)$ also , recorded higher values in compared to sprouts this might be due to role of photosynthesis which caused increasing in sprouts weight under effect of light, that explain the increase in loss of Dry Matter content in the sprouted trail, where plant consumed dry matter via respiration when there is no light provided during the early stage of implantation ,so the rat of loses of DM slowed down ,when leaves began photosynthesizing (21).On the other hand (Truby, 22) observed that the Seeds soaking might be caused the leaching of nutrients by a series of events lead to oxidation of substrates stored in the grain causing loss in DM , organic mater and water imbedded into the embryo of the seeds caused dissolved plant hormone Giberelic Acid (GA) which transported with water into the aleurone layer of seed, and activate DNA, leading to translate amino acids present into the (enzyme amylase) and released it into the endosperm where catalyses the hydrolysis of starch into its simple component (glucose unites) and using it immediately in metabolic activities within a young growing plant and finally yielded in oxidation generation of ATP and releasing carbon dioxide .In addition to that Trubey et.al.,(20) declare in the study that Dry Matter was less than 20 percent in case of sprouted barley but more than 90 percent in initial grain and because the low levels of dry matter content there were a limited effect on animal feed intake of green fodder . Organic matter As well as dry matter in sprouts, reported a significantly $(\mathrm{p}<0.05)$ lower value in compared to barley grain , the loses in dry matter content fully applies to organic matter since it consists the largest component of the dry matter to both sprouts and grains . furthermore , Morgan et.al.,( (23) reveled that via, implantation period organic matter especially starch consumed by plant to support the metabolism and energy requirements of growing Baker. et.al.,( (24) , Mayer,(26), were explain in studies that after 6 days of sprouting, starch accounted for $53-67 \%$ of the dry weight of barley seed, so any decrease in the amount of starch would cause a corresponding decrease in OM, DM NFC in forage , and report summarized by. Sneath . et. al., (14)was confirmed that the short growing cycle of sprouts provide a little chance for OM ,DM accumulations ,and most of the loses in them were as a result in respiration . On the other hand, current study is fully agree with study declared that Crud Protein as Dry matter basis in sprouts significantly $(<0.05)$ recorded higher values in compared to the origin grain ,this might be due to a change in weight of carbohydrate used in providing energy to the seeds through the respiration ,such increasing in the crud protein \% was likely due to the loses in the carbohydrate as Dry Matter since, there was no nitrogen source added externally to the water for irrigation during sprouting ,this Crud Protein \% increase was therefore not a likely true increase Chavan et.al.,(25), Cuddeford, (26), although true protein showed non significant effects. However, conversion ratio of crude protein and non protein nitrogen in sprouts also was significantly $(\mathrm{P}<0.05)$ increased compared to origin grain , the protein content may be influenced as a result of the level of supplementation and other nutrients changes in sprouting grains Peer et.al., (6), Morgan et.al.,(23). Ether Extract also, recorded significantly $(\mathrm{P}<0.05)$ higher in sprouts compared to origin grain , this could be due to the production of chlorophyll associated with plant growth that are recovered in ether extract measurement , however, Ether Eextract, NDF ,ADF also were increase content with fresh weight produce Peer et.al., (6) - neutral detergent fiber (NDF), acid detergent fiber (ADF) also were increased, but non-fiber carbohydrates (NFC) decreased in sprouted barley compared to the barley grain on a Dry Matter basis. Such changes not true, since they only describe the alterations in the proportion of nutrients during seven days of sprout in barley grain Morgan et.al.,( (23).

\subsection{Rumen characters}

\section{Rumen pH:}

Table (3) showed the $\mathrm{pH}$ of rumen fluid of the $30 \%$ treated group was significantly $(\mathrm{P}<0.05)$ lower than control groups, and $10 \%$ supplementation respectively which were showed the highest values in all sampling studied periods.

Table 3: The effect of replacement of barley by $10 \%$ and $30 \%$ sprouted barley in the diet on acidity of rumen fluids $(\mathrm{p} \mathrm{H})$ of Awassi male lambs (means $\pm \mathrm{SE}$ )

\begin{tabular}{|c|c|c|c|}
\hline Periods & \multicolumn{3}{|c|}{ Treatments } \\
\hline Period & $10 \%$ group & $30 \%$ group & Control group \\
\hline First test & $\begin{array}{c}6.50 \pm 0.11 \\
\mathrm{ab}\end{array}$ & $\begin{array}{c}6.12 \pm 0.00 \\
\mathrm{c}\end{array}$ & $\begin{array}{c}6.83 \pm 0.73 \\
\mathrm{a}\end{array}$ \\
\hline Second test & $\begin{array}{c}6.33 \pm 0.22 \\
\mathrm{~b}\end{array}$ & $6.11 \pm 0.06$ & $\begin{array}{c}6.82 \pm 0.13 \\
\mathrm{a}\end{array}$ \\
\hline Third test & $\begin{array}{c}6.21 \pm 0.11 \\
\mathrm{ab}\end{array}$ & $\begin{array}{c}6.14 \pm 0.07 \\
\mathrm{c}\end{array}$ & $\begin{array}{c}6.80 \pm 0.63 \\
\mathrm{a}\end{array}$ \\
\hline
\end{tabular}

Different letters show significant differences among treatments at one period at5\% level

\section{Protozoa activity}

Table (4) showed that the activities of protozoa of rumen fluids the $30 \%$ and $10 \%$ treated groups recorded significantly $(\mathrm{P}<0.05)$ higher values than $10 \%$ and control group Also the $30 \%$ group showed higher degrees in 


\section{International Journal of Science and Research (IJSR) \\ ISSN (Online): 2319-7064 \\ Index Copernicus Value (2013): 6.14 | Impact Factor (2015): 6.391}

protozoa activities of rumen fluids than the control group which were recorded the lower value.

Table 4: The effect of replacement of barley grain by $10 \%$ and $30 \%$ sprouted barely in the diet on the protozoa activities of rumen of Awassi male lambs ( means $\pm \mathrm{SE}$ )

\begin{tabular}{|c|c|c|c|}
\hline Period & \multicolumn{3}{|c|}{ Treatment } \\
\hline Period & $\begin{array}{c}\mathbf{1 0 \%} \\
\text { group }\end{array}$ & $\begin{array}{c}30 \% \\
\text { group }\end{array}$ & $\begin{array}{c}\text { Control } \\
\text { group }\end{array}$ \\
\hline First test & $\begin{array}{c}\mathbf{2 . 4 6} \pm \mathbf{0 . 7 1} \\
\text { ab }\end{array}$ & $\begin{array}{c}\mathbf{2 . 9 0} \pm \mathbf{0 . 7 3} \\
\text { a }\end{array}$ & $\begin{array}{c}\mathbf{1 . 5 9} \pm \mathbf{0 . 8 5} \\
\text { b }\end{array}$ \\
\hline $\begin{array}{c}\text { Second } \\
\text { test }\end{array}$ & $\begin{array}{c}\mathbf{2 . 3 2} \pm \mathbf{0 . 1 6} \\
\text { ab }\end{array}$ & $\begin{array}{c}\mathbf{2 . 8 8} \pm \mathbf{0 . 1 3} \\
\text { a }\end{array}$ & $\begin{array}{c}\mathbf{1 . 6 7} \pm \mathbf{0 . 3 6} \\
\mathbf{b}\end{array}$ \\
\hline Third test & $\begin{array}{c}\mathbf{2 . 4 3} \pm \mathbf{0 . 2 2} \\
\text { ab }\end{array}$ & $\begin{array}{c}\mathbf{2 . 8 0} \pm \mathbf{0 . 6 3} \\
\text { a }\end{array}$ & $\begin{array}{c}\mathbf{1 . 8 6} \pm \mathbf{0 . 6 6} \\
\mathbf{B}\end{array}$ \\
\hline
\end{tabular}

b Moderate activity

a High activity

\section{Volatile fatty acids:}

Table (5) showed that volatile fatty acids values of rumen fluid of the $30 \%$ treated groups significantly $(\mathrm{P}<0.05)$ higher values than those in the control group. Also, 10\% Group were significantly $(\mathrm{P}<0.05)$ higher values than control group.

Table 5: The effect of replacement of barley by $10 \%$ and $30 \%$ sprouted barely in diet on volatile fatty acids of rumen (equivalent $\mathrm{mol} / 100 \mathrm{ml}$ ) of Awassi male lambs ( means \pm

$\mathrm{SE})$

\begin{tabular}{|c|c|c|c|}
\hline period & \multicolumn{3}{|c|}{ Treatment } \\
\hline Period & $\mathbf{1 0 \%}$ group & $\mathbf{3 0 \%}$ group & Control group \\
\hline First test & $\mathbf{9 . 5 6} \pm \mathbf{0 . 3 7}$ & $\mathbf{1 1 . 9 8} \pm \mathbf{0 . 5 4}$ & $\mathbf{8 . 3 3} \pm \mathbf{0 . 4 3}$ \\
& b & a & c \\
\hline Second test & $\mathbf{9 . 7 7} \pm \mathbf{0 . 6 2}$ & $\mathbf{1 1 . 8 5} \pm \mathbf{0 . 2 7}$ & $\mathbf{8 . 3 8} \pm \mathbf{0 . 3 1}$ \\
& b & a & c \\
\hline Third test & $\begin{array}{c}\mathbf{9 . 7 5} \pm \mathbf{0 . 1 3} \\
\end{array}$ & $\mathbf{1 2 . 7 0} \pm \mathbf{0 . 1 5}$ & $\mathbf{8 . 6 1} \pm \mathbf{0 . 1 1}$ \\
& a & c \\
\hline
\end{tabular}

Different letters show significant differences among treatments at one period at5\% level table (3), shown there was a significant $(<0.05)$ low $\mathrm{pH}$ value of treated groups compared with control group ,since Optimal $\mathrm{pH}$ of healthy rumen at range of 6-7, so, any elevation or reduction indicate to physiological alteration of the rumen environment, such as high activity of microflora or excessive amount of volatile fatty acids yielded from fast and high utilization of diet, however the high activity ,and elevation in amount of volatile fatty acids occur specially in $30 \%$ and $10 \%$ supplementation sprouts groups respectively , compared to control group,(table 4,5$)$ such results agree with Mustavangwa et.al.,(15) who declare in study that reduce in $\mathrm{pH}$ value reflex carbohydrate fermentation in the rumen and absorption of the volatile fatty acids, Newbold et.al.,(16), also, Bach-lglesias et.al., ( 17) showed reduction in $\mathrm{pH}$ value and increased in total microorganisms by using probiotic as a feed additive, further Grenet ,(18) explain in study, that newly ingested sprouts are colonized by microbes in the rumen but the degradation is not immediate, bacteria colonies the feed at about eight hours and protozoa after two hours while fungal spores after 15 minutes, the fungal spore took three hours to produce hyphae to degraded the plant cells walls and make them fragile for bacteria and protozoal degradation, however, they were of opinion that higher intakes for the sprouts leaf material allowed for greater bacteria degradation and a shorter retention time within the reticulo-rumen Ulyatt, et.al.,(19)all that above ,explain the increasing in microflora activity levels and high amount of volatile fatty acids yielded with $\mathrm{pH}$ reducing value particularly in 30\% group treated group compared with control and $10 \%$ groups respectively.

\section{C - Feed digestibility}

Table (6) shown that treated groups specially $30 \%$ sprouts supplementation group recorded higher significantly $(<0.05)$ values in Dry matter digestibility, Organic matter digestibility, Crude protein digestibility and Ether extract digestibility respectively than $10 \%$ sprouts supplementation group and control group respectively ,except in Crude fiber digestibility in which treated groups particularly $30 \%$ group , recorded significantly $(<0.05)$ the lowest values compared to control group which were was recorded the lowest value.

Table 6: Digestion coefficients (\%) of the experimental diets (on DM basis).

\begin{tabular}{|c|c|c|c|}
\hline item & $\mathbf{1 0 \%}$ group & $\mathbf{3 0 \%}$ group & $\begin{array}{c}\text { Control } \\
\text { group }\end{array}$ \\
\hline Dry matter & $71.76 \pm 2.40$ & $72.09 \pm 3.32$ & $62.77 \pm 0.90$ \\
digestibility (DMD) & $\mathrm{b}$ & $\mathrm{a}$ & $\mathrm{c}$ \\
\hline Organic matter & $76.35 \pm 1.51$ & $78.77 \pm 0.28$ & $75.52 \pm 0.88$ \\
digestibility (OMD) & $\mathrm{b}$ & $\mathrm{a}$ & $\mathrm{c}$ \\
\hline Crude protein & $74.10 \pm 3.22$ & $82.50 \pm 0.4$ & $56.39 \pm 0.90$ \\
digestibility (CPD) & $\mathrm{b}$ & $\mathrm{a}$ & $\mathrm{c}$ \\
\hline Crude fiber & $53.95 \pm 0.91$ & $48.39 \pm 3.8$ & $55.34 \pm 5.91$ \\
digestibility (CFD) & $\mathrm{b}$ & $\mathrm{c}$ & $\mathrm{a}$ \\
\hline Ether extract & $86.10 \pm 1.6$ & $87.93 \pm 0.3$ & $70.78 \pm 2.62$ \\
digestibility (EED) & $\mathrm{ab}$ & $\mathrm{a}$ & $\mathrm{c}$ \\
\hline
\end{tabular}

abc Means in the same row with different letters are significantly different $(\mathrm{P}<0.05)$

Table (6) shown a significant $(<0.05)$ higher values in most contents of feed digestibility, except in the crud fiber digestibility in which treated groups particularly $30 \%$ and $10 \%$ supplementation respectively recorded the lowest value , however this results were mostly agree with Laredo et.al.,(27) who reported in study that addition of sprouted barley increased Dry Matter, Organic Matter, Crud Protein , Ether Extracts , and Crud Fibers, digestibility, this might be due to high content of leafy and roots portions contents of sprouts which is easy to digest and hydrolysis by the enzymes of rumen microflora, as well as enzymatic digestion(proteases) present in the lytic vacuoles of plant cells . Kingston et.al.,(28), Feller (29) also were confirmed that these enzymes are commence initial degradation of protein in the rumen in few hours of forage ingestion . Similarly Shipard (30) observed there is an increase in nutrient digestibility by the addition of sprouted grains in the diet of ruminants. Peer et.al., (6), as well as , Morgan et.al.,(23) were reported that OM and DM digestibility were in maximum by the addition of old sprouted barely., this study also in fully occurance with Moghaddam.et.al., (31) who determine the effect of sprouts on nutrient digestibility at the level of $0,33,66$ and $100 \%$, nutrient digestibility was increased by increasing the level of sprouted barley and was confirmed that the 100\% replacement resulted in better nutrient digestibility as compared to other levels. In 


\section{International Journal of Science and Research (IJSR) \\ ISSN (Online): 2319-7064}

Index Copernicus Value (2013): 6.14 | Impact Factor (2015): 6.391

Contrary to these progress Dung et.al.,( (32) , Sneath et.al.,( (14) were revealed that there were non-significant effect of sprouted grains on nutrient digestibility, on the other hand other researchers observed that there is a relationship between particle size of sprouts feed composition which were facilitate forming microbial colonies in the rumen and accelerate feed digestibility and passage rate Ehle (33), Laredo et.al., (27). In addition to that , surface area for microbial attachment and subsequent degradation have another aspect of digestibility that make ruminants favors the leaf portion above the stem of sprouts, specially in sheep which, consumed more tropical grass leaves than stem Popp.et.al., (34). Current study ,in good a agreement with Nutrgrass (35) , who declare that the roots comprised of interwoven mass with the seeds husk which housed the endosperm at seeds formation, the husk of seeds has high in fiber that made up of cell wall polysaccharides such as cellulose and hemi-cellulose that are usually more resistant to digestion than leave, This explains the decline in the value of crud fiber digestibility in both of $10 \%$ and $30 \%$ treated groups compared to control group

\section{References}

[1] ATLAS Global Crop. LTD. (2004). "Feeding Animal to feed People".Retrieved from: world wide web: www.atgloco.com

[2] Tudor, G., Darcy, T., Smith, P. and Shallcross, F. 2003. The Intake and LiveWeight Change of DroughtThomas, T.A., 1977. An automated procedure for the determination of soluble carbohydrate in herbage. Journal of Science of Food and Agriculture, 28: 639642.

[3] World wild-green field hydroponic (2003). Retrieved from world wide web: www.grassfield- hydroponic.com

[4] Steven H, Ext-Umberger (1996). Feed Sheep Extension AnimalScientist Virginia Cooperative Extension.

[5] Thomas, T.A., 1977. An automated procedure for the determination of soluble carbohydrate in herbage. Journal of Science of Food and Agriculture, 28: 639642.

[6] Peer, D.J. and S. Leeson, 1985b. Feeding value of hydroponically sprouted barley for poultry and pigs. Animal Feed Science and Technology, 13: 183-190.

[7] AOAC. 1995. Official Methods of Analysis. Association of Official Analytical Chemists,Inc., Washington,DC. , USA

[8] AOAC. 1999. Official Methods of Analysis. Association of Official Analytical Chemists,Inc., Arlington, Virginia, USA.

[9] Yuangklang; C., Vasupen; K., Wongsuthavas; S., Bureenok; S., Panyakaew; P., Alhaidary; A., Mohamed; H.E. and Beynen; A.C. (2010).Effect of replacement of soybean meal by dried tomato pomace on rumen fermentation and nitrogen metabolism in beef cattle. Am. J. Agri. \& Biol. Sci., 5: 256-260.

[10] AL-Ani:A. N. (1985)b study of associative effects of untreated and ammoniated wheat straw and alfa-alfa fed to sheep .PhD.Thesis ; Oklahoma state .USAb(( cited by AL-rashedy ; A.K.T 2001)).

[11] Joshi;B.C., Aravindan ;M., singh ; K. Bahattachary ;N.K (1971) ( effect of high environmental temperature stress on the physiological responses of bucks .Indian
.J.of Anim .Si.; 47(4): .((cited by Al rashedy; A.K.T . 2001)).

[12] M.J.AL-SAADI ., M.N.AL-SAIGH .,D.A .,S.B. ALARA.(2010)., ( Effects of Nigella sativa and /or trigonella -Foenum graecum seeds on some Productive and Physiological traits of Awassi Ram Lambs)., Baghdad university - college of veterinary medicine., Ph.D thesis.

[13] Snedecor ; G. W. and Cochran; W.G.(1973). Statical Methods 6 th (ed). The Iowa State University Press.USA

[14] Sneath, R. and F. McIntosh, 2003. Review of hydroponic fodder production for beef cattle. Department of Primary Industries: Queensland Australia 84. McKeehen, pp: 54.

[15] Mustavangwa; T., Edwards; I.E and Topps ; J .H. (1992) .the effect of dietary inclusion of yeast culture (Yea-Sac)on patterns of rumen fermentation, food intak and growth of intensively of feed bulls . Anim .Prod.; 55:35-41.

[16] Newbold ; C. J ., Wallace ; R. J ., Chen ; X. B .and Maclntosh ; F.M. (1995). Different strains of Sacchromyces cererisae differe in the effects on ruminal bacterial numbers in vitro and in sheep . J. Anim .Sci .; 73: 1811-1818.

[17] Bach-lglesias ; C .and Devant ; M . (2007). Daily rumen $\mathrm{pH}$ and live yeast supplementation . Anim . Feed Sci . Technol , 136 : 156 -163

[18]Grenet ,E.,1997.Microscopical Aspects of rumen microbial colonization and degradation of forage tissues .Prod. anim ., 10:241-249.

[19] Ulyatt,M.J.,D.W.Dellow and A.john,1986.Contrbution of chewing During eating and rumination to clearance of Digesta from ruminoreticulum prentice Hall Engelwood Cliffs ,new Jersey.

[20] Trubey, C.R. and Y. Otros, 1969. Effect of Light, World Journal of Agricultural Sciences, 6(6): 713-719.Culture Solution and Growth Period on Growth and Chemical Composition of Hydroponically Produced Oat Seedlings. Agronomy Journal, 61: 663-665.

[21] O"Sullivan,J.,1982.Possible effects in culture of barley seedlings compared to barley seeds as fodders .Department of horticulture, University College Dublin.

[22] Bautista, S. H. 2002. Producción de Forraje Verde Hidropónico de Trigo Triticum Aestivum L. para el Antenimiento de Conejos Criollos Oryctolagus Cuniculus. Thesis. Universidad Autónoma de Guerrero (UAG) Chilpancingo, Guerrero, México.

[23] Morgan, J., R.R. Hunter and R. O'Haire, 1992. Limiting factors in hydroponic barley grassproduction. In the proceeding of the 8th International congress on soil less culture, pp: 241-261.

[24] Baker, J. F., Vann, R. C. and Neville, W. E. Jr. 2002. Evaluations of Genotype $\square \square$ Environment Interactions of Beef Bulls' Performance Tested in Feedlot or Pasture. J. Anim. Sci., 80(7): 1716-1724.

[25] Chavan , J.K. and S.S Kadam , 1989. Nutrtional improvement of cereals by sprouting .Critical Rev.food Sci. Nutr., 28:401-437.

[26] Cuddeford, D., 1989. Hydroponic grass .In Pract ., 11.211-214. 28:401-437.

[27] Laredo,M.A. and D.J.Mison ,1975a .The pepsin souble dry matter of leaf and steam fractions of grasses in 


\section{International Journal of Science and Research (IJSR) \\ ISSN (Online): 2319-7064}

Index Copernicus Value (2013): 6.14 | Impact Factor (2015): 6.391

relation to voluntary intak in sheep .Aust.J.Exp.Agric. Anim .Husband., 15:203-206.

[28] Kingston-Smith .A.H.R.J.Merry ， D.K.Leemans, H .Thomas and M.K.Theodrou , 2005. Evidence in support of a role for plant -mediated proteolysis in the rumen of grazing animals Br.J.Nutr., 93:73-79.

[29]Feller, U., 1986.Plant Proteolytic Enzymes in Relation to leaf Senescence In:CRC Press ,Boca Raton f.L., USA., pp:49-68.

[30] Shipard, I. 2005: How can I grow and use sprouts as living food? Stewart publishing

[31] Moghaddam, A.S., M. Mehdipour and B. Dastar. 2009. The determining of digestible energy and digestibility coefficients of protein, calcium and phosphorus of malt (Germinated Barley) in broilers. Inter. J. Poult. Sci. 8: 788-791.

[32] Dung, D. D., Goodwin, I. R., \& Nolan, J. V. (2010). Nutrient Content and in sacco Digestibility of Barley Grain and Sprouted Barley. Journal of Animal and Veterinary Advances, 9 (19), 2485-2492.

[33]Ehle, F.R., 1984.influence of feed particle density on particulate passage from rumen of holstin cow .J.Dairv Sci., 67:693-697.

[34] Popp ,D.P.,D.J. H.Ternouth ., Poppi,D.P.,D.J.Minson and J.H.Ternouth, 1981.studies of cattle and sheep eating leaf and stem fraction of grasses II .factors controlling the retention of feed in the reticulo-rumen .Augst,J.Agric. Res., 32:109-121.

[35] Nutrgrass ,2007.the jointing stage :When nutrients reach their peak http://www.nutrigrass.com/jointingstage.htm 